"This is the peer reviewed version of the following article: Mancewicz, A. (2016) Performing

Shakespeare in Europe. Literature Compass, 13: 711-723, which has been published in final form at http://dx.doi.org/10.1111/lic3.12340. This article may be used for non-commercial purposes in accordance with Wiley Terms and Conditions for Self-Archiving." 


\title{
Performing Shakespeare in Europe
}

\begin{abstract}
$^{1}$
The history of performing Shakespeare in Europe and the establishment of European Shakespeare Studies have been closely connected with European culture and politics. The emergence of the European Shakespeare Research Association, ESRA, has coincided with the fall of Communism and the political transformations in Europe after 1989, as well as the growing professionalisation and internationalisation of Shakespeare criticism. In the twenty-first century, European studies of Shakespeare continue to flourish across Europe, with vibrant research centres extending from Murcia in Spain to Zaporizhzhia in Ukraine, and with a dynamic European Shakespeare Festivals Network. At the heart of European Shakespeare Studies has been the examination of Shakespeare's reception in different national traditions across Europe. Performance criticism has played a crucial role in this process, given that theatre as a medium transcends linguistic barriers, while encouraging local traditions of translation and staging. Productions of Shakespeare have also provided a forum for articulating current political and social concerns, particularly in times of censorship, which has made them exceptionally appealing to scholars interested in national cultures and histories. This article outlines four aspects that represent Shakespeare's relationship with European performance: theatrical exchanges between England and the Continent as the beginning of the European Shakespeare tradition, translation as an integral part of stage practice, the significance of performance criticism in European Shakespeare Studies, and the notion of a shared European theatre tradition. The discussion combines elements of a historical narrative with a critical overview.
\end{abstract}


The article concludes with new perspectives in twenty-first century Shakespeare productions, as the Eurozone debt crisis and immigration crisis pose new challenges and responsibilities for artists and academics.

\section{Introduction}

Shakespeare has always been a European playwright. Both a borrower and a lender, he drew on European cultures and participated in their development through his dramas. In 2014, when Gdańsk Shakespeare Theatre opened with a performance of Hamlet from London's Globe, the event celebrated four centuries of the playwright's connection with the Continent. The Gdańsk Theatre was built at the presumed site of a playhouse where English Comedians staged scripts of Shakespeare and his contemporaries in the first half the seventeenth century (Figures 1 and 2). The Globe's production, directed by Dominic Dromgoole and Bill Buckhurst to be performed from 2014 to 2016 in every country in the world (Hamlet Globe to Globe), was itself staged as a touring show, put together by iterant actors in front of the audience. The device foregrounded the theme of travelling players in Hamlet and the history of the English companies acting Shakespeare's plays on the Continent in his lifetime. Since then, Shakespeare's dramas have been translated into numerous languages and performed in various versions and venues. As part and parcel of social and political transformations in Europe, Shakespeare's plays have participated in shaping national cultures in England and on the Continent from the early theatrical exchanges onwards.

\section{Early Theatrical Exchanges}


Taking Shakespeare's dramas across the Channel, English players initiated the tradition of productive exchanges between England and the Continent in the reception of the playwright. From circa 1590 s to 1660 s, the actors toured with several plays of Shakespeare and his contemporaries and performed them in different venues, ranging from a fair in Frankfurt am Main to a ducal castle in Königsberg, now Russian Kaliningrad. The troupes travelled vast areas that on today's maps extend from the Netherlands to Latvia, and they presented Shakespeare's dramas to audiences from varying social, religious and cultural backgrounds. Touring often imposed severe limitations, resulting in extensive revisions of plays. The adjustment of the scripts to the expectations of the audience and the conditions of staging to some extent paralleled the practice of companies in England, in Shakespeare's times and later. The first published version of Hamlet, the First Quarto from 1603, is considered by many scholars to have been an acting copy, cut and adapted by a London-based company for a provincial tour (Dawson 1760-1761). Following the reopening of the theatres in 1660, Shakespeare's dramas were revived in altered versions, such as Nahum Tate's The History of King Lear (1681) or Colley Cibber's Richard III (1699); these adaptations dominated English stages well until the middle of the nineteenth century.

The activity of the English players on the Continent was important in terms of popularising Shakespeare's plays, even if it did little to popularise the author himself. The name of the playwright did not appear in print on the Continent until the publication of Unterricht von der Teutschen Sprache und Poesie by Daniel Georg Morhof in Kiel in 1682 (J. G. Robertson, "The Knowledge" 105). ${ }^{2}$ It is crucial, however, to foreground the impact of the English companies not only on Shakespeare's European reception but also specifically on European theatre, emphasising the vital cultural links between England and the Continent. English 
actors enriched local performance cultures, in which the playwright would thrive for centuries to come (Williams 45; Stříbrný 24), and they revolutionised stage practice. Some of their innovations, such as the inclusion of actresses, the extensive use of Italian scenery and operatic music, preceded stage developments in England (Hotson 171). Despite this, the significance of English actors has been rarely acknowledged and "can be too easily disparaged" (Williams 45). This might be because the tradition of Shakespeare translation was not yet fully established, but also because a century after their return to England, the contribution of English players was overshadowed by the dominance of new cultural tastes: French Neoclassicism and later German Romanticism. These two critical traditions started a new trajectory for the reception of Shakespeare in Europe, which did not draw directly on the work of the seventeenth century touring companies. According to Simon Williams, "there is scant evidence of continuity between the drama of seventeenth-century wandering troupes and the critical and theatrical emergence of Shakespeare in the latter half of the eighteenth century" (27). In the twentieth century, touring productions of English players were seldom seen as an integral part of the national reception of Shakespeare in Europe. ${ }^{3}$

In the last few decades, the role of English companies on the Continent has been reassessed, thanks to illuminating accounts of their work (Haekel; KujawinskaCourtney; Limon; Williams; Stříbrný). The growth of theatre and performance research within Shakespeare Studies has further validated the importance of stage practice. In the twenty-first century, scholars have more readily acknowledged that the travelling actors played a key part in the European tradition. Zdeněk Stř́brný wrote enthusiastically, "Their visits to the Continent represent one of the most intriguing chapters in the annals of British and European theatre" (6). Their stage experimentation showed that the works of Shakespeare and his fellow dramatists 
"were unusually adaptable to any geographical location, staging condition, social milieu, and religio-political situation" (Stříbrný 23). The English players were the first ones to undertake linguistic and cultural transfer of Shakespeare's dramas, initiating the process of their assimilation and appropriation outside England and the English language.

\section{Translation}

Initially, the English actors performed in their native language, which meant that they had to simplify the lines and the plots to non-Anglophone spectators (Williams 2932). Busy cosmopolitan cities had large English-speaking communities, with Gdańsk being "arguably the largest English colony on the Continent" (Stř́brný 10), yet most spectators would rely on physical comedy, juggling and clowning. Later, English companies began to employ German or Dutch players to communicate directly with the audiences (Stř́ibrný 9), while the scripts were translated into German, often in prose and with elements of dialect. Throughout the seventeenth century, single Shakespeare's plays were published in German and a few in Dutch. The webpage of the university of Basel Sh:in:E project gives a useful overview of translations into different European languages ("Shakespeare Translations in Europe"). There are no records, however, of complete translations of Shakespeare in Europe until the second half of the eighteenth century.

The first collected and then complete translations of Shakespeare's dramas were in German and French, and they influenced translation and indirectly also performance practice in other countries in Europe. Between 1762 and 1766 twentytwo plays appeared in German prose translation by Christoph Martin Wieland. Between 1775 and 1782, Johann Joachim Eschenburg revised Wieland's work, 
producing the first complete translation of Shakespeare in German. Another complete translation in German, published in 1833 as the work of August Wilhelm von Schlegel and Ludwig Tieck, became a masterpiece of the German language. Eschenburg's edition coincided with the first French complete translation: Pierre Le Tourneur's twenty volumes were published between 1776 and 1783. These prose translations were aimed for the page rather than for the stage, and they have only indirectly influenced versions of Shakespeare's plays in verse that were produced for performance. In the second half of the eighteenth century, Jean-François Ducis produced six adaptations of Shakespeare's plays in verse; not knowing English, he based them on prose translations by Pierre-Antoine de la Place and later on those by Le Tourneur. Ducis's versions were performed at Comédie Française for several decades, and they were frequently translated and staged by companies in Spain, Italy, the Netherlands, Poland, and Russia (Gregor, “The Imprint of France” 137). Ducis's case was not an exception, as French and German translations served as intermediaries in Shakespeare's theatrical reception in different European countries, inspiring local performance traditions.

In the nineteenth and twentieth centuries, Shakespearean staging in Europe has coincided with the development of national identities and the creation of modern nation states. The plays were translated into a number of European languages, initially from French and German and then from English. Translations of Shakespeare have been part of the development of different languages in Europe, in the spirit of Romantic efforts to establish national literary canons. At the same time, they were produced to assert the advancement of national languages and cultures, showing them as capable of rendering the complexity of Shakespeare's poetry and philosophy. This was vital for European nations struggling for independence in the nineteenth and 
twentieth centuries. Stanisław Helsztyński, for example, writes that "Poles, both at home and in exile after the November Uprising of 1830, felt the need of Polish literature to possess the whole of Shakespeare in translation" (22). In the twenty-first century, translation continues to be an essential element of Shakespeare performance and reception in Europe, as well as Shakespeare criticism, which is testified by wideranging essay collections on the subject (Delabastita and D'hulst, European Shakespeares; Hoenselaars, Shakespeare and the Language of Translation; Homem and Hoenselaars).

The interdependence of translation and performance practice becomes most evident when directors commission new versions of Shakespeare's plays for a particular production. ${ }^{4}$ This frequently happens in countries with established dramaturgical practice, which confirms a close link between translation and dramaturgy, foregrounded by Maria João da Rocha Afonso (163). Afonso was asked to translate Richard II for the National Theatre in Lisbon after she had worked as a dramaturge, and she has been keenly aware of challenges of a stage translation, which requires a deep understanding of theatrical practice. In the last decade, there have been several examples of successful collaborations between directors and translators / dramaturges on productions of Shakespeare in Europe. Directing Hamlet (2008) and Richard III (2015) Thomas Ostermeier worked with Marius von Mayenburg, a playwright and dramaturge. Stefan Pucher commissioned new translations from Jens Roselt, a scholar and dramaturge, when directing Der Sturm [The Tempest] for Münchner Kammerspiele (2007) and Der Kaufmann von Venedig [The Merchant of Venice] for Schauspielhaus Zürich (2008). Gabriele Vacis directed Romeo \& Juliet for Teatro Stabile Torino (2005) working on a text which Pietro Deandrea, scholar and translator, produced together with Marco Ponti, writer and film director. As 
Deandrea explains in an informative article about his contribution, "the English text underwent cuts and modifications (beside some original insertions), so that it ended up coasting on the shifty borderline between translation and adaptation; the published caption goes 'raccontato da [narrated by] $\square$ Marco Ponti e Pietro Deandrea"” (123). In each of these cases, a new translation resulted in a new interpretation, aimed for a specific venue, actors, and audience. Translations have thus participated in the development of staging styles and audience expectations, while making Shakespeare's dramas part of national cultures, as well as European culture more broadly.

\section{Performance Criticism}

Even though Shakespeare has been part of Continental culture from circa 1590, it was only four hundred years later that the investigation of Shakespearean staging in Europe became a distinct research area with a pan-European perspective and a strong sense of interrelations between the UK and the Continent. The key moment came in the 1990s, which saw "[t]he steady rise of the self-acknowledged European Shakespeareans" and the establishment of the European Shakespeare Research Association, ESRA (Hoenselaars and Calvo). ${ }^{5}$ It was a critical time in the history of Europe. The Fall of the Iron Curtain, the unification of Germany and the dissolution of the Soviet Union, Czechoslovakia and Yugoslavia brought out hopes and fears about the future of individual countries and the formation of a new Europe. Political and social transformations were difficult, complex, and at times violent, with Yugoslav wars unleashing the horrors of ethnic cleansing and sexual crimes. In this troubled time, Shakespeare's works were evoked in the academia and the arts to redefine national identities and to search for a pan-European identity that would 
transcend the boundaries between East and West. In a highly symbolical act, the Deutsche Shakespeare-Gesellschaft [DSG, German Shakespeare Society] was reunited in 1993, after three decades of division into Eastern and Western branches (Deutsche Shakespeare-Gesellschaft). Scholars and theatre makers from countries on both sides of the Curtain were given a chance to travel freely across Europe and exchange ideas. The new opportunities of collaboration led to a number of conferences on Shakespeare's appropriation held around Europe. ${ }^{6}$

In its early stages of development, ESRA met with several challenges within and outside Europe. For a long time approaches to the playwright's presence on the Continent focused on France and Germany, as in the works of J. G. Robertson ("Shakespeare on the Continent"), Augustus Ralli, and Paul S. Conklin. It was assumed that "the major contributions to continental Shakespeare criticism have been French and German, perhaps because of the early development of interest in Shakespeare in these two countries, as well as the presence of two powerful critics, Voltaire and Lessing" (LeWinter 24). This, combined with the dominance of French Neoclassicism and German Romanticism and the influence of French littérature comparée and German Komparatistik on comparative literature as an international discipline, meant that the study of Shakespearean appropriations in other European nations had received less scholarly attention. Moreover, European Shakespeare Studies had to establish their position in relation to Anglophone scholarship. Several Anglophone scholars have keenly supported the development of ESRA and have made significant contributions to its activities and publications over the years. However, an American scholar, Douglas Bruster saw European Shakespeare Studies, which he derogatively labelled as "EU Shakespeare", as anti-American, whereas a British scholar, Thomas Healy, expressed anxiety over the preservation of 
Shakespeare's Elizabethan and Jacobean origins in the light of dynamically developing studies and appropriations of the playwright in Europe. Healy's rejection of Bulgarian and Croatian claims to Shakespeare as part of the common European heritage was eloquently exposed by Márta Minier (180-185). Such attitude might to some extent explain the long history of omissions and misconceptions regarding the complex relationships between English and Continental appropriations of Shakespeare. $^{7}$

Parallel to confronting these obstacles, European Shakespeare scholars have striven to define the key methodological approaches within the field. From the beginning, they have acknowledged the essential role of theatre in European Shakespeare reception, alongside research in other areas, such as translation, history, opera, dance, film, or literature. When in 1998 "Shakespeare in Europe", Sh:in:E, research project was founded at the University in Basel by Balz Engler and Werner Brönnimann with a team of scholars including Markus Marti and Ladina Bezzola Lambert, to study Shakespeare's role in European culture, it underlined the importance of theatre and drama (Shakespeare in Europe). The popularity of performance criticism within the field gave rise to a great number of conference papers and essay collections on adapting, directing, acting, spectating, and reviewing Shakespeare in different countries.

Several factors might explain the significance of stage criticism within Shakespeare Studies in Europe. Performance has been the primary mode of transmitting Shakespeare's dramas internationally, from the times of English players until the present, since the use of such means as actors' bodies, movements, music, sets, and costumes allows for communication that does not exclusively depend on linguistic comprehension. This might seem paradoxical, given that Shakespeare is 
universally renowned for the quality of his language, but European countries have also long traditions of Shakespeare translations. They have produced masterly works that became part of the nations' literary heritage, such as the aforementioned Schlegel-Tieck's versions that are the landmark of German literature.

As a medium that both transcends linguistic barriers and encourages local traditions of translation and staging, theatre has been particularly well suited for the reception and study of Shakespeare's plays outside England. Stage productions of Shakespeare in Europe offer particularly valuable material to discuss social and artistic traditions in different countries. They do not depend on the linguistic competence of the spectators, but they still give them a glimpse of a foreign theatrical tradition and society. In this spirit, the Sh:in:E project in Basel argued that theatre offers an exceptional insight into cultures, as "it is there that cultures constantly rearticulate their concerns, registering, even anticipating changes that take place", while drama enables the study of intercultural relationships, since it "facilitates the comparison of these geographically and historically different articulations" (Shakespeare in Europe).

It is because of this localised nature that theatre can take the pulse of current events. As a practice originating in a specific time and place and aimed at a specific audience, theatre may give voice to social concerns, and this capacity becomes crucial in times of oppression and unrest. "Under totalizing regimes, theatre had long served as a forum for debate before revolution moved into the Parliament Square", note Michael Hattaway, Boika Sokolova and Derek Roper in their discussion of Shakespeare performance in the New Europe (17). Productions of Shakespeare proved exceptionally suitable for political interpretations behind the Iron Curtain. As Marta Gibińska and Jerzy Limon explain, "the text itself was "safe" and could not be 
treated by the censor as detrimental to the interests of the state; on the other hand, stage action, characterisation, costume, stage set and even music, could create meaningful signs within a current cultural code" (13). Given the history of censorship, occupation, and dictatorship in Europe, it is not surprising that artists and scholars are frequently drawn to Shakespeare as a manifestation of not only artistic trends but also political issues.

The importance of performance analysis within European Shakespeare Studies owes, however, not only to the intrinsic nature of theatre as a medium and its historical role, but also to the development of this research area against wider changes in staging and Shakespeare scholarship in the last two decades of the twentieth century. In the 1980s, Performance Studies emerged in the United States to foreground the centrality of performance practice and to advocate for interdisciplinary and intercultural approaches to theatre. Broadening the notion of performance, the new discipline encouraged the production and the study of experimental and politically conscious theatre, which has paved way for alternative approaches to staging Shakespeare. At the same time, the rise of Shakespeare performance criticism, which was stimulated by J. L. Styan's 1977 book The Shakespeare Revolution (Love 741), has resulted in a greater focus on social and cultural conditions of theatre and theatre scholarship. ${ }^{8}$ Finally, since the 1990 s there has been a growing interest in global approaches to Shakespeare, inspired by the publication of Dennis Kennedy's Foreign Shakespeare in 1993. This essay collection on non-Anglophone Shakespeare productions has stimulated further research on international and intercultural approaches to Shakespeare. Ton Hoenselaars and Ángel-Luis Pujante, distinguished ESRA members, observed that while the book's primary focus was global, "it did 
much to encourage" the development of European Shakespeare Studies, which they rightly saw as "the rising wave" (17).

In the twenty-first century, European Shakespeare Studies continue to flourish. Germany and France are still renowned for vibrant Shakespeare scholarship, but there is also a wealth of academic activity across the Continent, from Murcia (Shakespeare in Spain Within the Framework of His European Reception) to Zaporizhzhia (Ukrainian Inter-university Shakespeare Research Centre). Scholarly events are frequently organised in conjunction with Shakespeare theatre festivals, as in the case of the well-established International Shakespeare Festival in Craiova, Romania, and a newly launched York International Shakespeare Festival in the UK (both of which are part of the lively European Shakespeare Festivals Network). This further fosters relationships between academia and the theatre, while contributing to a shared tradition of European Shakespeare performance.

\section{European Shakespeare Tradition}

Defining the tradition of European Shakespeare theatre is daunting. The linguistic and cultural diversity of Shakespearean productions, as well as the long history of European Shakespeare appropriation force one to select and generalise. The inclusion and the exclusion of styles and artists from particular nations may in turn raise questions about central and marginal cultures within Europe. Finally, the very focus on European reception of Shakespeare can potentially lead to accusations of "selfcomplacent Eurocentrism" or "Europhilia", from which Dirk Delabastita, Jozef De Vos and Paul Franssen clearly distance themselves when explaining their approach to European Shakespeare (15). In short, one might be well advised to abandon the definition altogether. 
Nevertheless, the distinctiveness of theatre practice and Shakespeare reception in Europe becomes apparent, once the performances travel beyond it. When in 2008 Grzegorz Jarzyna brought 2008: Macbeth (TR Warszawa) to St. Anne's Warehouse in New York and when in 2012 Ivo van Hove's Romeinse tragedies [Roman Tragedies] (Toneelgroep, Amsterdam) were staged in Brooklyn Academy of Music, audiences and critics recognised a uniquely European tone in their approaches to Shakespeare. Jarzyna's production was identified as a typical example of Continental practice because of its reliance on a directorial concept. An American critic, Michael Miller protested, "Not Macbeth but Regietheater. This is certainly not the first time Regietheater has appeared over here, but fortunately, it has not taken over to the extent it has on the Continent". Van Hove's staging received a more favourable reception, while it was also labelled as unmistakably European. An American theatre scholar, James N. Loehlin observed, "Roman Tragedies is characteristic of a European propensity for epic Shakespeare productions - epic both in the sense of large-scale and political, and in the sense of reflecting the ongoing importance in European theatre of the theories of Bertolt Brecht" (1). The reference to Regietheater as the tradition of "director's theatre" which originated in Germany, and the evocation of Brecht suggest that what is seen as European from an American perspective is German-influenced. More broadly, the reception of these two productions in New York shows that European Shakespeare performances are seen as part of a shared theatre tradition, despite differences in individual directors' styles. This suggests that "United in Diversity", the European Union motto adopted in 2000, could be well applied to European stagings of Shakespeare.

European performance, and performance of Shakespeare in particular, might be seen as a network of relationships: productions have distinctive styles, yet they are 
interrelated aesthetically and ideologically. The claim hinges on two assumptions: that we can speak of a common European culture and that there are significant similarities between theatrical takes on Shakespeare in different European countries. Both these claims are highly contentious, since Europe is geographically, politically and culturally heterogeneous (Bezzola and Engler 13), whereas Shakespeare stands for an array of meanings that can "refer to a person, to a set of printed texts, to a cultural icon, to a theatrical tradition, or to a combination of all of these" (Engler 27). Acknowledging these complexities, Bezzola Lambert and Engler still contend, however, that "Europe should be viewed as one cultural area" (12), while "Shakespeare highlights differences as well as a shared heritage" (12). A critical awareness of cultural and political differences within Europe and beyond is fundamental for the study of European Shakespeare performance as a shared tradition.

It is also vital to remember that such shared tradition is an ideological construct - supported not only by public funding from local and national governments, as well as the EU - but also by European settings of the plays, the intercultural make up of Europe, and the common threads in Shakespeare's reception. Shakespeare used Greek and Roman sources that form the basis of European culture, and he referenced several European nations. Hamlet is a particularly good example, since according to Manfred Pfister, "in no other play by Shakespeare are so many European countries and nations drawn into the plot" (17). These features of the plays form the basis of Shakespeare's status as a European playwright. The perception is further enhanced by a sense of a shared European culture, bound together by geography, politics, economy, language, intellectual ideas, arts, and scholarship. Even though Europe's geography is unstable and to some extent perennially undefined, given continuous political and cultural changes (Engler 28), the very instability of the 
internal and external borders, along with the geographic proximity of different countries are precisely the factors that encourage intercultural exchanges within Europe. It becomes manifest in the case of the players travelling between England and the Continent in the early modern period, as well as in the case of contemporary practitioners working across borders, particularly in linguistically similar areas, such as the Netherlands and Flanders, or Germany, Austria and Switzerland. Strong historical ties between European nations, forged through royal marriages, military alliances and peace treaties, have further contributed to the sense of a shared Shakespeare tradition. In 1993 political relations between European countries found their new legal framework with the establishment of the European Union, which reinforced economic interdependences across the region and established transnational agendas for culture and scholarship. Finally, productions of Shakespeare in different European countries share a similar history of appropriation, due to the remarkable role of French and German translations and the intertwining of two tendencies in Continental criticism, Neoclassic and Romantic. All these factors have contributed to the interconnected and interdependent nature of Shakespeare staging in Europe.

Perhaps the best way to conclude this section is to turn again to a theatrical example. In 1996 Karin Beier directed A Midsummer Night's Dream at Schauspielhaus Düsseldorf, with "14 actors speaking nine different languages (German, English, Italian, Polish, Russian, Hungarian, Bulgarian, Hebrew, French)”, whom she "had personally hand-picked from theatres around Europe" (Boecker 5). Hailed as "ein europäischer Shakespeare [a European Shakespeare]", the staging was aptly described by Bettina Boecker, as an attempt at "theatrical identity constitution" (4). It responded to the enthusiasm surrounding the construction of a unified Europe, 
proclaimed in the Schengen Agreement (signed in 1985, fully incorporated since 1995) and the Maastricht Treaty (1992) (Boecker 4). Two decades after Beier's Dream, however, the EU is in danger of break up, while the border-free travel under the Schengen Agreement is under debate. The European crisis of the last few years poses new challenges and responsibilities for artists and academics working on European Shakespeare performance, as shown in the next and last section.

\section{New Perspectives in $21^{\text {st }}$ Century Europe}

In June 2012, the UK was in the middle of the World Shakespeare Festival, a cultural counterpart to the Olympic Games. The Festival showcased British and international theatre companies to celebrate the playwright's global outreach. Among the plays produced by the RSC was The Comedy of Errors directed by a Palestinian theatre maker, Amir Nizar Zuabi. It premiered in Stratford-upon-Avon in spring and was brought to Roundhouse Theatre in London in the summer.

It was clear from the beginning that Zuabi's production stretched the limits of comedy. The stage was set in busy docklands, patrolled by armed police forces. Syracusan Antipholus, played by Jonathan McGuinness, and Syracusan Dromio, portrayed by Bruce Mackinnon, arrived in Ephesus as illegal immigrants in shipping containers. In the opening scene, Egeon, portrayed by Nicholas Day, who was guilty of violating strict migration laws between Syracuse and Ephesus, was subject to water torture, and in the last act, his body was suspended on a rope. The moments of terror were skilfully interwoven with glimpses of ingenuous physical and verbal humour. This was particularly evident as the immigrants were trying to outsmart the authorities, selling fake designer items, while on the run from the police. The comedy was in full swing, until right before the interval one of the immigrants got shot by a 
police officer. As the lights went on, there was a moment of silence. The ensuing applause seemed strangely at odds with the cold blood killing witnessed on stage.

The sinister overtones in Zuabi's production brought out dark elements from Shakespeare's comedy, in a provocative portrayal of contemporary immigration policies, global economic inequalities, and the acts of political violence. In the midst of festive celebrations, these issues seemed distant to many spectators and critics in the UK; at most the politics in the performance was read as a far-away echo of the Israeli-Palestinian conflict, given the director's nationality. A Wall Street Journal reviewer remarked, "Though many of the Ephesians are armed and dressed in policestate black, Mr. Zuabi's sense of fun soon gets the better of him, and he treats us to the best-rehearsed slapstick comedy since "One Man, Two Guvnors"“ (Levy 2012). In hindsight, however, the production seems even more ominous and manifests a broader set of problems that are conspicuous also in other stagings of Shakespeare in recent years.

Zuabi's Comedy of Errors represents a wider trend in the twenty-first century European theatre of staging Shakespeare's plays to comment on political and economic crisis in Europe. A similar concern may be found in Van Hove's Romeinse tragedies (2007), set in a contemporary news room, in Nora Somaini's Der Kaufmann von Venedig (Bremer Shakespeare Company, Bremen 2007), where the focus is on Antonio as a modern businessman, in Sebastian Kautz's Timon aus Athen (Bremer Shakespeare Company, 2010), with allusions to the European debt crisis, and in Nicholas Hytner's Timon of Athens (National Theatre, London 2012), which includes striking references to corporate sponsorship, Occupy Protest, and London's 2011 riots. Well received by national and international audiences, these productions reinterpret Shakespeare's dramas in the light of local and global tensions shortly 
before and after the financial crisis of 2007-2008. Looking at its repercussions, Marilena Zaroulia and Philip Hager describe the new situation as an "inside / outside Europe' conundrum", which after 2008 has radically reframed Europe, "both the idea and the geopolitical formation, at once exclusive and privileged" (1). In the light of the European debt crisis which began in 2009, the migrant crisis and Paris attacks, both in 2015, and Brussels attacks in 2016 the "inside / outside Europe's conundrum" turns into a pressing political question. As a result, the Europeans have to re-examine the meanings of unity and diversity - the notions that they once proclaimed as their shared values. The aftermath of this process will have an immense impact on Shakespearean staging and scholarship.

Writing about Shakespeare's role in Europe, Delabastita, De Vos and Franssen have made an important remark that "Europe's politics are not and have never been stable or homogeneous" (14). This observation puts the current European crisis into perspective, yet without making it less disturbing. In the twenty-first century, Shakespearean productions in Europe continue to address contemporary problems and struggles. According to Bezzola Lambert and Engler, "Shakespeare on the stage cannot but be politicized", because it "reaches a much wider, less professional audience than Shakespeare scholarship, which causes it to be more alive and linked to present concerns" (17). Over the centuries, Shakespearean performances in different European countries have repeatedly responded to local and regional politics. Shakespeare has always been a European playwright - with the notions Shakespeare and Europe in constant revision and perpetually redefining each other. 


\section{Works Cited}

Afonso, Maria João da Rocha. "From Words to Action." Translating Shakespeare for the Twenty First Century. Eds. Rui Carvalho Homem and Ton Hoenselaars. Amsterdam - New York: Rodopi, 2004. 163-80. Print.

Bauer, Roger. Das Shakespeare-Bild in Europa zwischen Aufklärung und Romantik. Bern: Peter Lang, 1988. Print.

Bezzola Lambert, Ladina, and Balz Engler. Introduction. Shifting the Scene: Shakespeare in European Culture. Eds. Ladina Lambert Bezzola and Balz Engler. Newark: University of Delaware Press, 2004. 11-18. Print.

Boecker, Bettina. "Europe speaks Shakespeare” - Karin Beier's 1996 "A Midsummer Night's Dream”, Multilingual Performance and the Myth of Shakespeare's Linguistic Transcendence. European Shakespeare Association Conference, Montpellier, France, June 2013. Unpublished conference paper. Print.

Bruster, Douglas. "The Anti-Americanism of EU Shakespeare." The Shakespearean International Yearbook 8: Special Section, European Shakespeares. Eds. Bradshaw, Graham, Tom Bishop, Ton Hoenselaars, and Clara Calvo. Aldershot: Ashgate, 2008. 97-106. Print.

“Conferences." ESRA. University of Murcia. Web. 25 Nov. 2015. <http://www.um.es/shakespeare/esra/conferences/>

Conklin, Paul S. A History of "Hamlet” Criticism 1601-1821. New York: Humanities Press, 1968. Print. 
Dawson, Anthony B. "Textual Introduction to Hamlet." The Norton Shakespeare. Eds. Stephen Greenblatt et al. 3rd ed. New York and London: W. W. Norton \& Company, 2016. 1760-1763. Print.

Deandrea, Pietro. "You Kiss Like in a Movie': A Contemporary Translation/Adaptation of "Romeo and Juliet." Reinventing the Renaissance: Shakespeare and His Contemporaries in Adaptation and Performance. Eds. Sarah Annes Brown, Robert I. Lublin and Lynsey McCulloch. Basingstoke: Palgrave Macmillan. 122-140. Print.

Deutsche Shakespeare-Gesellshaft. Web. 25 Nov. 2015. <http://www.shakespeare-gesellschaft.de/en/society.html >

Delabastita, Dirk, Jozef de Vos, and Paul Franssen. "General Introduction." Shakespeare and European Politics. Eds. Dirk Delabastita, Jozef de Vos and Paul Franssen. Newark: University of Delaware Press, 2008. 13-26. Print.

Delabastita, Dirk, and Lieven D'hulst, eds. European Shakespeares. Translating Shakespeare in the Romantic Age. Amsterdam / Philadelphia: John Benjamins Publishing, 1993. Print.

Delabastita, Dirk, and Lieven D'hulst. "Introduction." European Shakespeares. Translating Shakespeare in the Romantic Age. Eds. Dirk Delabastita and Lieven D’hulst. Amsterdam / Philadelphia: John Benjamins Publishing. 1993. 9-24. Print.

Engler, Balz. "Constructing Shakespeare in Europe." Four Hundred Years of Shakespeare in Europe. Eds. Ángel-Luis Pujante and Ton Hoenselaars. Newark: University of Delaware Press, London: Associated University Press, 2003. 26-39. Print. 
Erne, Lukas. Shakespeare as Literary Dramatist. Cambridge: Cambridge University Press, 2003. Print.

European Shakespeare Festivals Network. Web. 25 Nov. 2015. 〈http://esfn.eu〉

Haekel, Ralf. Die englischen Komödianten in Deutschland. Heidelberg : Winter, 2004. Print.

Healy, Thomas. "Past and present Shakespeares: Shakespearian appropriations in Europe.” Shakespeare and National Culture. Ed. John J. Joughin. Manchester: Manchester University Press, 1997. 206-232. Print.

Gibińska, Marta, and Jerzy Limon. "Introduction.” Hamlet East-West. Eds. Marta Gibińska and Jerzy Limon. Gdańsk: Theatrum Gedanense Foundation, 1998. 11-15. Print.

Globe to Globe Hamlet. Shakespeare's Globe. Web. 25 Nov. 2015.

<http://www.shakespearesglobe.com/theatre/whats-on/globe-theatre/hamletglobe-to-globe>

Gregor, Keith. Shakespeare in the Spanish Theatre: 1772 to the Present. London I New York: Continuum, 2009. Print. "The Imprint of France: French Hamlet and Spanish Neoclassicism."

The Hamlet Zone: Reworking Hamlet for European Cultures. Ed. Ruth J. Owen. Newcastle Upon Tyne: Cambridge Scholars Publishing, 2012. 137150. Print.

Hamburger, Maik. "Translating and Copyright." Shakespeare and the Language of Translation. Ed. Ton Hoenselaars. London: Arden Shakespeare, 2004. 148166. Print.

Hattaway, Michael, Boika Sokolova, and Derek Roper, "Introduction.” Shakespeare in the New Europe, a collection of conference papers. Eds. Michael Hattaway, 
Boika Sokolova and Derek Roper. Sheffield: Sheffield Academic Press, 1994. 15-21. Print.

Helsztyński, Stanisław. "The Fortune of Shakespeare in Poland.” Poland's Homage to Shakespeare. Commemorating the Fourth Centenary of His Birth 1564-1964. Ed. Stanisław Helsztyński. Warszawa: PWN, 1965. 5-33. Print.

Hoenselaars, Ton. "Foreword." Shakespeare and European Politics. Eds. Dirk Delabastita, Jozef de Vos and Paul Franssen. Newark: University of Delaware Press, 2008. 9-11. Print.

Honeselaars, Ton, ed. Shakespeare and the Language of Translation. London: Arden Shakespeare, 2004. Print.

Hoeneslaars, Ton and Clara Calvo. "European Shakespeare: A Brief History." ESRA. University of Murcia. Web. 25 Nov. 2015.

〈https://www.um.es/shakespeare/esra/history.php>

Hoenselaars, Ton, and Ángel-Luis Pujante. "Shakespeare and Europe: An Introduction." Four Hundred Years of Shakespeare in Europe. Eds. ÁngelLuis Pujante and Ton Hoenselaars. Newark: University of Delaware Press, London: Associated University Press, 2003. 15-25. Print.

Homem, Rui Carvalho, and Ton Hoenselaars, eds. Translating Shakespeare for the Twenty First Century. Amsterdam - New York: Rodopi, 2004. Print.

Hotson, Leslie. The Commonwealth and Restoration Stage. Cambridge: Harvard University Press, 1928. Print.

Kennedy, Dennis, ed. Foreign Shakespeare: Contemporary Performance. Cambridge: Cambridge University Press, 1993. Print.

Kujawińska-Courtney, Krystyna. "Shakespeare in Poland: Selected Issues." Internet Shakespeare Editions. University of Victoria. 2006. Web. 25 Nov. 2015. 
$<$ http://internetshakespeare.uvic.ca/Library/Criticism/shakespearein/poland1.h tml>

LeWinter, Oswald. Shakespeare in Europe. Cleveland and New York: The World Publishing Company, 1963. Print.

Levy, Paul. "Slapstick Shakespeare in Stratford.” Wall Street Journal. 26 April 2012. Web. 25 Nov. 2015.

< http://www.wsj.com/articles/SB100014240527023034255045773557008523 $\underline{17204>}$

Limon, Jerzy. Gentlemen of a Company: English Players in Central and Eastern Europe 1590-1660. Cambridge: Cambridge University Press, 1985. Print.

Loehlin, James N. Epic Shakespeare: Ivo Van Hove's "Roman Tragedies." Shakespeare Association in America Conference, Toronto, Canada, March 2013. Unpublished conference paper. Print.

Love, Genevieve. “Shakespeare and Performance.” Literature Compass 6.3 (2009): 741-757. Blackwell Publishing Ltd. Web. 25 Nov. 2015.

Miller, Michael. “TR Warszawa: Grzegorz Jarzyna's Macbeth 2008 by the Brooklyn Bridge.” Rev. of 2008: Macbeth, dir. Grzegorz Jarzyna. New York Arts. 13 November 2013. Web. 25 Nov. 2015. <http://newyorkarts.net/2008/07/trwarszawa-grzegorz-jarzyna-macbeth-2008/>

Minier, Márta "Claiming Shakespeare as 'Our Own'." Shakespeare in Europe: History and Memory. Eds. Marta Gibińska and Agnieszka Romanowska. Kraków: Jagiellonian University Press, 2008. 177-185. Print.

Palomo, Juan. “Adaptaciones.” El Cultural. 18 July 2014. Web. 22 Dec. 2015. <http://www.elcultural.com/revista/opinion/Adaptaciones/34989> 
Pfister, Manfred. "Polish and German Hamlets in Dialogue." Hamlet East-West. Eds. Marta Gibińska, and Jerzy Limon. Gdańsk: Theatrum Gedanense Foundation, 1998. 16-31. Print.

Pujante, Ángel-Luis. "Interpretar a Shakespeare.” El Cultural. 18 April 2014. Web. 22 Dec. 2015. <http://www.elcultural.com/revista/escenarios/Interpretar-aShakespeare/34513>

Ralli, Augustus. A History of Shakespearian Criticism. 2 vols. London: Oxford University Press, 1932.

Robertson, J. G. “The Knowledge of Shakespeare on the Continent at the Beginning of the Eighteenth Century." The Modern Language Review. 1.4 (1906): 312321. EBSCOhost. Web. 25 Nov. 2015.

"Shakespeare on the Continent." The Cambridge History of English

Literature. Eds. A. W. Ward and A. R. Waller. 5 vols. Part 1. Cambridge: Cambridge University Press, 1910. 282-308. Print.

Shakespeare in Europe. Sh:in:E. University of Basel. Web. 25 Nov. 2015.

$<\underline{\text { https://shine.unibas.ch/home.html }>}$

Shakespeare in Spain Within the Framework of His European Reception. University of Murcia. Web. 25 Nov. 2015.

〈http://www.um.es/shakespeare/proyecto.php?lang=en_EN>

"Shakespeare Translations in Europe." Shakespeare in Europe. Sh:in:E. University of Basel. Web. 25 Nov. 2015. <https://shine.unibas.ch/translators.htm>

Stř́brný, Zdeněk. Shakespeare and Eastern Europe. Oxford: Oxford University Press, 2000. Print.

Ukrainian Inter-university Shakespeare Research Centre. Web. 25 Nov. 2015. 〈http://shakespeare.zp.ua > 
Williams, Simon. Shakespeare on the German Stage: Volume 1, 1586-1914. Cambridge: Cambridge University Press, 1990. Print.

Zaroulia, Marilena, and Philip Hager. "Introduction: Europe, Crises, Performance.” Performances of Capitalism, Crises and Resistance: Inside/Outside Europe. Eds. Marilena Zaroulia and Philip Hager. Basingstoke: Palgrave, 2015. 1-13. Print.

Bibliography

Bezzola Lambert, Ladina, and Balz Engler, eds. Shifting the Scene: Shakespeare in European Culture. Newark: University of Delaware Press, 2004. Print.

Bradshaw, Graham, Tom Bishop, Ton Hoenselaars, and Clara Calvo, eds. The Shakespearean International Yearbook 8: Special Section, European Shakespeares. Aldershot: Ashgate, 2008. Print.

Bragaglia, Leonardo. Shakespeare in Italia. Personaggi ed interpreti. Vita scenica del teatro di Guglielmo Shakespeare in Italia, 1792-1973. Rome: Trevi editore, 1973. Print.

Calvo, Clara. "Shakespeare in Spain: Current Research Trends." Literature Compass. 6.4 (2009): 942-956. Blackwell Publishing Ltd. Web. 25 Nov. 2015.

Chambers, E.K., Elizabethan Stage. Vol. 2. Oxford: Clarendon Press, 1923. Print. Cinpoeş, Nicoleta. Shakespeare's Hamlet in Romania, 1779-2008: A Study in Translation, Performance, and Cultural Adaptation. Lewiston, N. Y.: Edwin Mellen Press, 2010. Print.

Cohn, Albert. An Account of English Actors in Germany and the Netherlands: And of 
the Plays Performed by Them During the Same Period. London : Asher \& Co, 1865.

Dente, Carla, and Sara Soncini, eds. Shakespeare and Conflict. A European Perspective. Basingstoke: Palgrave Macmillan 2013. Print.

Delabastita, Dirk, Jozef de Vos, and Paul Franssen, eds. Shakespeare and European Politics. Newark: University of Delaware Press, 2008. Print.

Dobson, Michael. The Making of the national poet: Shakespeare, adaptation and authorship, 1660-1769. Oxford: Clarendon Press, 1995. Print.

Farr Jeannie, and Benedict Schofield. "Shakespeare and the Euro-crisis: The Bremer Shakespeare Company Timon aus Athen." Shakespeare Beyond English. A Global Experiment. Eds. Susan Bennett and Christie Carson. Cambridge: Cambridge University Press, 2013. 287-292. Print.

Gibińska, Marta, and Jerzy Limon, eds. Hamlet East-West. Gdańsk: Theatrum Gedanense Foundation, 1998. Print.

Gibińska, Marta, and Agnieszka Romanowska, eds. Shakespeare in Europe: History and Memory. Kraków: Jagiellonian University Press, 2008. Print.

Guntner, Lawrence J. and Andrew M. McLean. Redefining Shakespeare. Literary Theory and Theatre Practice in the German Democratic Republic. Newark: University of Delaware Press, 1998. Print.

Hattaway, Michael, Boika Sokolova, and Derek Roper, eds. Shakespeare in the New Europe, a collection of conference papers. Sheffield: Sheffield Academic Press, 1994. Print.

Herz, Emil. Englische Schauspieler und englisches Schauspiel zur Zeit Shakespeares in Deutschland. Hamburg and Leipzig: L. Voss, 1903. Print. 
Hoenselaars, Ton. "Bibliography: Shakespeare in European Culture.” Four Hundred Years of Shakespeare in Europe. Eds. Ángel-Luis Pujante and Ton

Hoenselaars. Newark: University of Delaware Press, London: Associated University Press, 2003. 241-259. Print.

Hoenselaars, Ton and Clara Calvo. "European Shakespeare on Either Side of the Channel." Shakespeare. 3:1 (2007): 102-107. Print.

Hortmann, Wilhelm. Shakespeare on the German Stage: Volume 2, The Twentieth Century. Cambridge: Cambridge University Press, 2009.

Marx, Peter W., ed. Hamlet Handbuch. Stoffe, Aneignungen, Deutungen. Stuttgart and Weimar: Verlag J. B. Metzler, 2014. Print.

Owen, Ruth J., ed. The Hamlet Zone: Reworking Hamlet for European Cultures.

Newcastle Upon Tyne: Cambridge Scholars Publishing, 2012.

Reinelt, Janelle. "Performing Europe: Identity Formation for a "New" Europe.”

Theatre Journal. 53: 3 (2001): 365-387. The John Hopkins University Press. Print.

Schandl, Veronika. Socialist Shakespeare productions in Kádár-Regime Hungary: Shakespeare behind the Iron Curtain. Lewiston, N.Y.: Edwin Mellen Press, 2008. Print.

Shurbanov, Alexander, and Boika Sokolova. Painting Shakespeare Red: An EastEuropean Appropriation. London: Associated University Presses, 2001. Print. Wells, Stanley. Shakespeare for All Time. London: Macmillan, 2002. Print.

\section{Figures}

1. The Gdańsk Shakespeare Theatre with the city view; photo by Rafał Malko, courtesy of the Gdańsk Shakespeare Theatre. 
2. The Interior of the Gdańsk Shakespeare Theatre; photo by Dawid Linkowski, courtesy of the Gdańsk Shakespeare Theatre.

${ }^{1}$ I would like to thank Dr. Bettina Boecker, Prof. Ángel-Luis Pujante and anonymous reviewers for their invaluable comments and suggestions for this article. I am also grateful to Prof. Jerzy Limon and the Gdańsk Shakespeare Theatre for the permission to use images of the Gdańsk Theatre.

${ }^{2}$ In the second half of the eighteenth century, Shakespeare's name was still not fully established across Europe. When Hamlet was performed in 1772 at the Corral del Príncipe theatre in Madrid, in Jean-François Ducis's version translated into Spanish by Ramón de la Cruz, "One name not on the lips of the spectators who sat facing the Príncipe's new proscenium was that of William Shakespeare" (Gregor, Shakespeare in the Spanish Theatre 7).

${ }^{3}$ In a historical overview of the Polish Shakespeare tradition, published in 1965 , Stanisław Helsztyński wrote, "Such isolated performances we do not [...] count as part of the history of Shakespeare's reception in Poland" (7).

${ }^{4}$ Regrettably, versions of Shakespeare's plays used on stage do not always acknowledge the copyrights of the translators. Maik Hamburger, Juan Palomo and Pujante criticise the practice of combining published Shakespeare translations into "adaptations" which do not recognise the rights of their authors. They discuss the existence of this phenomenon in their own countries - Germany and Spain - but it could be observed also in other parts of Europe.

${ }^{5}$ In these early stages, the debates within ESRA were influenced by some of the questions and claims in the essay collection Das Shakespeare-Bild in Europa zwischen Aufklärung und Romantik, edited by Roger Bauer and published in 1988. I am grateful to Prof. Pujante for drawing my attention to this volume. 
${ }^{6}$ European Shakespeares (Antwerp, 1990), Shakespeare in the New Europe (Bankya

- Sofia, 1993), and Four Hundred Years of Shakespeare in Europe (Murcia, 1999).

Since then, every two years in a European city there has been a major conference with a European focus (a full list may be found under "Conferences" at the ESRAwebsite). The events resulted in the publication of important essay collections on European Shakespeares. They are listed in the Bibliography, along with a selection of monographs, essay collections and journal issues on the subject.

${ }^{7}$ Looking back at the links between English Studies and Shakespeare's reception in Europe until 1990s, Dirk Delabastita and Lieven D'hulst observed, “on the whole our understanding of the multiple ways in which the English images of Shakespeare depend on interactions with Continental traditions is fairly erratic, and usually limited to the canonized layers of Shakespeare's afterlife" ("Introduction" 21).

${ }^{8}$ The rise of stage-centred studies has met with resistance from scholars like Lukas Erne, who famously argued that Shakespeare aimed his plays for print, as well as performance. 